\title{
Koronavírusjárvány: Tanulságok az egészségfejlesztési szakemberek számára
}

\author{
doi: 10.24365/ef.v61i1.575
}

Közhely, de most talán mégsem felesleges felhívni a figyelmet arra, hogy a fertőző betegségek terjedése alapvetően az emberek viselkedésétől függ. Másként fogalmazva, az egészségmagatartás járványügyi szempontból is kiemelkedő fontosságú. $A z$ egészségmagatartás változtatása pedig az egészségfejlesztés szakterülete, ezért az Egészségfejlesztés folyóirat szerkesztői néhány tanulság megfogalmazását már most - a járvány tetőzése előtt - is időszerúnek tartanak.

Megközelítésként válasszuk a viselkedésváltoztatás elméleti keretrendszerét! E szerint a viselkedést három tényezőcsoport befolyásolja: a képességek, a környezet és a motiváció.

Képességek. Először is el kell érni, hogy a fertőző betegségek terjedésével kapcsolatos ismeretek az egészségre vonatkozó tudás részévé váljanak. A gyermekek egészségnevelését, a felnőtteknek szóló felvilágosítást, az egészségkommunikációt e témában ésszerû megerősíteni. A lakosság személyes higiénére vonatkozó tudása és készségei mellett elemi járványügyi ismereteinek szélesítése elengedhetetlen a járványügyi biztonság növeléséhez.

Környezet. Másodszor, nagyobb figyelmet kell szentelni a gyermekintézményekben és a munkahelyeken a személyes higiénéhez szükséges körülmények biztosítására. El kell érni, hogy az alapvető tisztálkodási szabályok betartása mindennapi rutinná, szokássá formálódjon, de ehhez a szükséges tárgyi feltételeknek és időnek rendelkezésre kell állniuk.

Motiváció. Végül, a képességek és a környezet után nézzük a viselkedésváltoztatás harmadik elemét, a magatartást helyes irányba elmozdító motivációt! Amellett, hogy az egyének felismerik, saját érdekük a betegségek megelőzése, meg kell érteniük, hogy viselkedésük mások egészségére is döntő hatással lehet. A járványügyi szempontból is helyes magatartás követéséhez megfelelő közösségi normák, elvárások szükségesek. Ezek biztosítják, hogy „éles helyzetben", mint a mostani koronavírus-járvány, az emberek járványügyi szempontból, maguktól is célszerúen viselkedjenek.

A fentiek alapján világos az egészségfejlesztés elsődleges feladata: a betegségek és elterjedésük megelőzéséhez a lakosság viselkedésének befolyásolása, az azt támogató környezet kialakításának előmozdítása, azaz az ország egészségkultúrájának fejlesztése.

A magyar kormány operatív törzset hozott létre az új koronavírus elleni küzdelem érdekében.

- Az operatív törzs honlapján hiteles és naprakész információk találhatók a hatósági intézkedésekről, a megelözéshez szükséges lépésekröl és teendőkröl panaszok esetén: https://koronavirus.gov.hu

- Az operativ törzs jelen van a Facebookon is: "Koronavírus tájékoztató oldal" néven: https://facebook.com/102141028062794

- Kérdések feltehetök a nap 24 órájában müködö ügyeleti központnak telefonon, a 0680277455 és a 0680277456 ingyenesen hívható számokon, illetve

- irásban a következö e-mail címen: koronavirus@bm.gov.hu

A Nemzeti Népegészségügyi Központ (NNK) az Országos Tisztiföorvos vezetésével részt vesz $a z$ operativ törzs munkájában.

- Az NNK tájékoztató oldalt múködtet: https://www.nnk.gov.hu/index.php/lakossagitajekoztatok/koronavirus, valamint

- "Tisztiorvos" néven jelen van a Facebookon is: https://facebook.com/214579338566491"

Koronavírussal kapcsolatos aktuális utazási tanácsok az egyes országokra vonatkozóan elérhetők a Konzuli Tájékoztatás oldalon: https://konzuliszolgalat.kormany.hu/koronavirus

Szerkesztőség 